\title{
Hypolipidemic Mechanisms of Ananas comosus L. Leaves in Mice: Different From Fibrates but Similar to Statins
}

\author{
Weidong Xie ${ }^{1}$, Wei Wang ${ }^{2}$, Hui $\mathrm{Su}^{2}$, Dongming Xing ${ }^{2}$, Guoping Cai ${ }^{1}$, and Lijun $\mathrm{Du}^{2}{ }^{2 *}$ \\ ${ }^{1}$ Laboratory of Life Sciences \& Marine Biology, Life Sciences Division, Graduate School at Shenzhen, Tsinghua University, \\ Shenzhen 518055, China \\ ${ }^{2}$ Laboratory of Pharmaceutical Sciences, Department of Biological Sciences and Biotechnology, Tsinghua University, \\ Beijing 100084, China
}

Received October 6, 2006; Accepted December 6, 2006

\begin{abstract}
In this study, we investigated hypolipidemic mechanisms of the ethanolic extract of Ananas comosus L. leaves (AC) in mice and then determined its activities in related enzymes. The results showed that $\mathrm{AC}(0.40 \mathrm{~g} / \mathrm{kg})$ significantly inhibited the increase in serum triglycerides by $40 \%$ in fructose-fed mice. In mice induced by alloxan and high-fat diets, serum total cholesterol remained at a high level $(180-220 \mathrm{mg} / \mathrm{dl})$ within 7 days of removing high-fat diets but reached normal level $(120-140 \mathrm{mg} / \mathrm{dl})$ after AC $(0.40 \mathrm{~g} / \mathrm{kg}$ per day $)$ treatment. Also, AC $(0.40$ and $0.80 \mathrm{~g} / \mathrm{kg})$ significantly inhibited serum lipids from the increase in Triton WR-1339induced hyperlipidemic mice. AC $(0.01-100 \mu \mathrm{g} / \mathrm{ml})$ selectively activated lipoprotein lipase (LPL) activity by $200 \%-400 \%$ and significantly inhibited 3-hydroxyl-methyl glutaryl coenzyme A (HMGCoA) reductase activity by $20 \%-49 \%$ in vitro. Furthermore, 2 months of fenofibrate $(0.20 \mathrm{~g} / \mathrm{kg})$ administration particularly increased mice liver weights $(0.0760 \pm$ $0.0110 \mathrm{~g} / \mathrm{g})$ while AC $(0.40 \mathrm{~g} / \mathrm{kg})$ had no effect $(0.0403 \pm 0.0047)$. Taken together, these results suggest that $\mathrm{AC}$ will be a new potential natural product for the treatment of hyperlipidemia that exerts its actions through mechanisms of inhibiting HMGCoA reductase and activating LPL activities. Its action mechanisms differentiate from those with fibrates but may be partly similar to those with statins. It is hopeful that AC may serve as the adjuvant for fibrates.
\end{abstract}

Keywords: Ananas comosus L., hyperlipidemia, lipoprotein lipase, phenol, 3-hydroxyl-methyl glutaryl coenzyme A (HMGCoA) reductase

\section{Introduction}

Hyperlipidemia is one of important risk factors involved in the development of cardiovascular disease (1). Treatment of hyperlipidemia involves diet control, exercise, and the use of lipid-lowering diets and drugs (2). However, some patients cannot tolerate the adverse effects from these oral drugs (3). As a consequence, there continues to be a high demand for new oral antihyperlipidemic drugs. Management of hyperlipidemia without any side effects is still a challenge to the medical system. Plant products are frequently considered to be less toxic and more free from side effects than synthetic

*Corresponding author. pharm@mail.tsinghua.edu.cn

Published online in J-STAGE

doi: 10.1254/jphs.FP0061244 ones. Plants play a major role in the introduction of new therapeutic agents and have received much attention as sources of biologically active substances including antioxidants, hypoglycemics, and hypolipidemics.

Ananas comosus (L.) MERRILL. (family Bromeliaceae), also, named pineapple, has long been one of the most popular of tropical and subtropical fruits. It is grown extensively in Hawaii, Philippines, Caribbean area, Malaysia, Taiwan, Thailand, Australia, Mexico, Kenya, South Africa, Hainan province of China and so on. Besides agricultural utilities such as being a fruit with nutritional value, some folk medicinal uses have been found. In Thailand, A. comosus was used as an indigenous medicinal plant $(4,5)$ for the treatment of dysuria. In China, A. comosus cortexes served as alexipharmic, antitussive, and antidiarrheal agents; and A. comosus leaves were usually used as an antidyspepsia 
or antidiarrheal agent in Chinese Traditional Medicine (6). In Australia, some molecules from A. comosus leaves are claimed to have an antitumor effect.

In our preliminary study, the ethanolic extract of $A$. comosus leaves (AC) enriched with phenols has antidiabetic, anti-hyperlipidemic, and anti-oxidative effects (7). Recently, we showed that the hypoglycemic effect of AC is related to improvement of insulin sensitivity (8). However, its hypolipidemic mechanism remains undetermined. Considering the complexity of both hypolipidemic mechanisms and components of $\mathrm{AC}$, we investigated the activities of AC in multi-models of mice and some enzymes related to lipid metabolism to elucidate its hypolipidemic mechanisms.

\section{Materials and Methods}

\section{Materials}

Blood glucose, total cholesterol, and triglyceride diagnosis kits were purchased from Zhongsheng Beikong High-tech Bio-engineering Co. (Beijing, China). Lipoprotein lipase (LPL) kits were obtained from Nanjing Jiancheng Bioengineering Co. (Nanjing, China). Fenofibrate was purchased from Beijing Medicinal Company (Beijing, China). Commassier bright blue (G250) was purchased from Xinjingke Co. (Beijing, China). Simvastatin was provided by Hangzhou MSD Pharmaceutical Co., Ltd (Hangzhou, Zhejiang, China). Alloxan, 3-hydroxyl-methyl glutaryl coenzyme A (HMGCoA), and pancreatic lipase were purchased from Sigma (St. Louis, MO, USA). Lipid emulsion (Intralipos ${ }^{\circledR}$ ) was provided by Guangzhou Green Cross Pharmaceutical Co., Ltd. (Guangzhou, Guangdong, China). The other chemicals used in this study were all reagent grade.

\section{Collection of plant material}

A. comosus leaves were collected from Boao, Hainan province of China and authenticated by Dr. Shouquan Lin, the Institute of Medicinal Plants, Chinese Academy of Medical Sciences. A voucher specimen (No. 020501) was deposited in the herbarium of Laboratory of Pharmaceutical Sciences, Department of Biological Sciences and Biotechnology, Tsinghua University. This plant was dried in the shade, powdered, and the powder was used for the ethanolic extraction.

\section{Plant extract}

Dried powder of $A$. comosus leaves was refluxed with $70 \%$ ethanol three times for $1 \mathrm{~h}$. Each extracted solution was condensed to a final concentration of $0.20 \mathrm{~g} / \mathrm{ml}$ (in terms of dried starting material). Then, the extracted suspension was allowed to stand for $10 \mathrm{~h}$ in the dark or

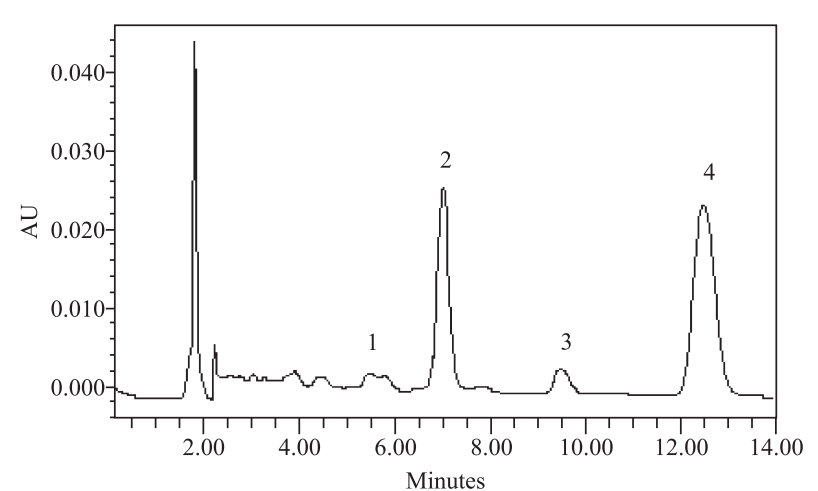

Fig. 1. HPLC of the ethanolic extract of Ananas comosus L. leaves: 1) 1-O-caffeoylglycerol, 2) caffeic acid, 3) 1-O-p-coumaroylglycerol, and 4) $p$-coumaric acid.

shade, and then the supernatant was eluted through a resin column (HPD-100; Cangzhou Bon Chemical Co., Ltd., Cangzhou, Hebei, China). The column for first eluted with distilled water until no sugar was detected (the eluate was more than 5 times the volume of the column). Subsequently, $80 \%$ ethanol was used to elute the column and this eluate was collected, condensed, and dried to the extract for use in the experiments. The yield of the ethanolic extract of $A$. comosus (AC) was $3.3 \%(\mathrm{w} / \mathrm{w}$ in terms of dried starting material). Phytochemical screenings of AC were conducted by Dr. Wei Wang, Department of Biological Sciences and Biotechnology, Tsinghua University. AC contained total phenols $(60 \%, \mathrm{w} / \mathrm{w}$ in terms of the extract). Known phenols included $p$-coumaric acid $(1.5 \%), 1-O-p$ coumaroylglycerol $(0.3 \%)$, caffeic acid $(1.0 \%)$, and $1-O$ caffeoylglycerol ( $0.2 \%)$ (See Fig. 1). Also, some sterols were found in the plant extract. The composition of the $\mathrm{AC}$ preparation was well-defined from the present results and allowed guaranteed a high standard of quality control for use in future studies.

\section{Animals}

Male ICR mice $(18-20 \mathrm{~g})$ and Wistar rats $(180-$ $200 \mathrm{~g}$ ) were obtained from the Laboratory Animal Institute of Chinese Academy of Medical Science (Beijing, China). Animals were kept in an environmentally controlled breeding room (temperature: $20 \pm 2{ }^{\circ} \mathrm{C}$, humidity: $60 \pm 5 \%, 12 \mathrm{~h}$ dark/light cycle) . They were fed standard laboratory chow with water ad libitum and fasted overnight before the experiments. Experimental animals were maintained in accordance with internationally accepted principles for laboratory animal use. Our research was conducted in accordance with the Declaration of Helsinki and/or with the Guide for the Care and Use of Laboratory Animals as adopted and promulgated by the United States National Institutes 
of Health.

Diabetes was induced in mice by the intraperitoneal (i.p.) administration of alloxan $(150 \mathrm{mg} / \mathrm{kg}$ body weight) as previously prescribed (9). Induction of diabetic hypercholesterolemia in mice was according to the previous method (10) with a slight modification, that is, diabetic mice were allowed free access to a high-fat diet (84.3\% standard laboratory chow, 5\% lard, $10 \%$ yolk powder, $0.2 \%$ cholesterol, $0.5 \%$ bile salt). In addition, normal rats were used to supply ample plasma containing LPL and livers for separation and purification of HMGCoA reductase, which were used to assay activities of the tested samples for LPL and HMGCoA reductase in vitro, respectively.

\section{Fructose load test}

Acute administration of fructose leads to a sharp increase in plasma triglyceride level in mice according to the previous method (11). Based on that, we made some modifications in the method. In brief, animals were divided into four groups of 10 mice each. Groups 1-3 were fed fructose to induce hypertriglyceridemia and group 4 was fed water as a normal control. Group 1 served as a fructose-fed hypertriglyceridemic control and received distilled water. The fructose-fed mice of group 2 were orally administered $\mathrm{AC}$ suspension in distilled water at a dose of $0.40 \mathrm{~g} / \mathrm{kg}$. The fructose-fed mice of Group 3 served as positive control treated with fenofibrate $(0.20 \mathrm{~g} / \mathrm{kg})$. Group 4 served as normal control mice treated with distilled water only. The administration of $\mathrm{AC}$ was continued for 3 days, once daily. The time to the last administration of the tested samples is at $5 \mathrm{~h}$ prior to the oral administration of fructose. Following that, mice were received a $20 \% \mathrm{~W} / \mathrm{V}$ fructose solution by gavage at a dose of $0.3 \mathrm{ml} / 10 \mathrm{~g}$ body weight at the start and then had free access to the fructose solution for $6 \mathrm{~h}$ after supplying neither diet nor water overnight. Following that, blood samples were collected for triglyceride assaying through tail veins. This trial was used to evaluate if AC could affect endogenous synthesis of triglycerides or not.

\section{Hypercholesterolemia progression test}

Diabetic mice were selected and well matched according to blood glucose and body weights in each group $(n=7)$. Simultaneously, they had free access to a high-fat diet for the induction of hypercholesterolemia, which was well developed in our previous study (10). Subsequently, AC $(0.40 \mathrm{~g} / \mathrm{kg})$ was orally administered in diabetic mice (Group 2). Diabetic (Group 1) and normal controls (Group 4) received distilled water. Positive controls (Group 3) were treated with fenofibrate suspension in distilled water at the oral dose of
$0.20 \mathrm{~g} / \mathrm{kg}$. After $4-5 \mathrm{~h}$ of fast, blood samples were collected for measuring total cholesterol level through tail veins on days $0,1,3,5$, and 7 of $\mathrm{AC}$ administration. This trial was used to evaluate if AC could inhibit dietary lipid or cholesterol absorption or not.

\section{Hypercholesterolemia regression test}

Diabetic mice were selected and fed a high-fat diet for the induction of the diabetic hypercholesterolemic animal model. Following feeding for two weeks, diabetic hypercholesterolemic mice were divided into three groups according to fasting blood glucose and total cholesterol levels. Subsequently, the fed high-fat diet was replaced with the low-fat regular chow in the diabetic hypercholesterolemic mice. Group 1 served as diabetic hypercholesterolemic controls treated with distilled water. Group 2 served as diabetic hypercholesterolemic mice treated with $\mathrm{AC}$ at the oral dose of $0.40 \mathrm{~g} / \mathrm{kg}$. Group 3 served as positive controls treated with a fenofibrate suspension in distilled water at the oral dose of $0.20 \mathrm{~g} / \mathrm{kg}$ and normal controls (Group 4) received distilled water only. After $4-5 \mathrm{~h}$ of fasting, blood samples were collected for measuring serum total cholesterol levels through tail veins on days $0,1,3,5$, and 7 of $\mathrm{AC}$ administration. This trial was used to evaluate if AC could accelerate cholesterol metabolism and/or inhibit cholesterol synthesis or not.

\section{Trial of Triton WR-1339-induced hyperlipidemic mice}

Animals were divided into five groups of 10 mice each. Group 1 served as normal control mice treated with distilled water only. Groups $2-5$ received an i.p. injection of Triton WR-1339 at a dose of $500 \mathrm{mg} / \mathrm{kg}$ (12). Group 2 served as control and orally received distilled water. Group 3 served as positive control treated with fenofibrate $(0.20 \mathrm{~g} / \mathrm{kg})$. The mice of groups $4-5$ were orally administered AC suspension in distilled water at doses of 0.40 and $0.80 \mathrm{~g} / \mathrm{kg}$, respectively. The administration of $\mathrm{AC}$ was continued for 2 days, once daily, which was conducted prior to $5 \mathrm{~h}$ of blood sample collection. Blood samples were collected for serum triglyceride and total cholesterol assaying at 24 and $48 \mathrm{~h}$ after injection of Triton WR-1339. This trial was used to evaluate if AC could activate inactive serum lipase and/or inhibit endogenous lipid synthesis and/or accelerate lipid metabolism or not.

\section{Trial of hepatomegly in mice}

Animals were divided into three groups of 10 mice each. Group 1 served as control and orally received distilled water. The mice of group 2 were orally administered AC suspension in distilled water at a dose of $0.40 \mathrm{~g} / \mathrm{kg}$. Group 3 served as positive controls 
treated with fenofibrate $(0.20 \mathrm{~g} / \mathrm{kg})$. After 2 months of treatment, mice were sacrificed by cervical dislocation and livers were removed and weighed. Since fenofibrate can activate peroxisome proliferators-activated receptor (PPAR) $\alpha$ and result in hepatomegly in rodents, this trial was used to determine if $\mathrm{AC}$ shared the same mechanism as fenofibrate or not.

\section{Measurements of pancreatic lipase, lipoprotein lipase, and $H M G C O A$ reductase activities in vitro}

Pancreatic lipase activity in vitro was assayed as prescribed previously (13) with a slight modification. In brief, the reaction mixture solution consisted of $0.1 \mathrm{ml}$ of (final concentration, $10 \mathrm{U} / \mathrm{ml}$ ) pancreatic lipase, $0.01 \mathrm{ml}$ of $20 \%$ lipid emulsion (Intralipos ${ }^{\circledR}$ ), $1 \mathrm{ml}$ of $0.1 \mathrm{~mol} / 1$ Tris- $\mathrm{HCl}$ buffer ( $\mathrm{pH} \mathrm{8.2)}$, and $0.79 \mathrm{ml}$ of distilled water, which was incubated at $37^{\circ} \mathrm{C}$ for $60 \mathrm{~min}$. Subsequently, free fatty acids produced by pancreatic lipase were extracted by $5 \mathrm{ml}$ of fatty acid extraction solution (chroroform/heptane/methanol, 49/49/2, $\mathrm{v} / \mathrm{v} / \mathrm{v}$ ). Following that, $2 \mathrm{ml}$ of extracted organic phase was combined with $2 \mathrm{ml}$ of $0.05 \mathrm{~mol} / 1 \mathrm{Cu}\left(\mathrm{NO}_{3}\right)_{2}$ reagent (contained supersaturated $\mathrm{NaCl}$ and $0.1 \mathrm{~mol} / 1$ triethanolamine) and formed complexes of free fatty acid and $\mathrm{Cu}^{2+}$. The complexes entered the water phase of the solution after extraction. Then, $0.5 \mathrm{ml}$ of extracted water phase containing the complexes was combined with $0.1 \mathrm{ml}$ of $4 \mathrm{mg} / \mathrm{ml}$ diphenyl carbazide (contained $0.1 \mathrm{~mol} / 1$ triethanolamine), and the solution immediately appeared red. Optical density of the final reaction solution was assayed at $550 \mathrm{~nm}$ within $30 \mathrm{~min}$. Free fatty acids produced by pancreatic lipase were quantified according to the standard curve plotted by different concentrations of palmitic acid solution $(0.1-1 \mathrm{mmol} / 1$ stock solution) and matched optical density values after palmitic acid exposed to similar treatment. Pancreatic lipase activity was determined as mmol fatty acid released per hour in $1 \mathrm{ml}$ of the reaction mixture at the start. The final concentrations of the tested samples incubated with the tested enzymes ranged from 0.01 to $100 \mu \mathrm{g} / \mathrm{ml}$.

LPL was prepared from the blood in rats 15 min after intravenous of heparin $(50 \mathrm{U} / \mathrm{kg})$; its activity in vitro was measured by the use of LPL kits according to the previous method (14) with a slight modification. Plasma total lipase activity was assayed and then hepatic lipase activity was measured after LPL activity was inhibited by high-concentration $\mathrm{NaCl}(0.79 \mathrm{~mol} / \mathrm{l}$, final concentration). LPL activity was calculated according to the formula: LPL activity $=($ serum total lipase activity $)-$ (serum hepatic lipase activity). In brief, the reaction mixture solution consisted of $0.1 \mathrm{ml}$ of plasma, $0.01 \mathrm{ml}$ of lipid emulsion, $1 \mathrm{ml}$ of $0.1 \mathrm{~mol} / 1$ Tris- $\mathrm{HCl}$ buffer
( $\mathrm{pH} 8.2), 0.79 \mathrm{ml}$ of distilled water (for total lipase activity assay), or high-concentration $\mathrm{NaCl}(0.79 \mathrm{~mol} / \mathrm{l}$, final concentration, for hepatic lipase assay) and incubated at $37^{\circ} \mathrm{C}$ for $60 \mathrm{~min}$. The following procedure performed according to the pancreatic lipase method described above. Lipoprotein lipase activity was expressed as mmol free fatty acid produced by plasma LPL per hour in $1 \mathrm{ml}$ of the reaction mixture solution at the start. The final concentrations of the tested samples incubated with the tested enzymes ranged from 0.01 to $100 \mu \mathrm{g} / \mathrm{ml}$.

The activity of HMGCoA reductase prepared from rat liver microsomes was assayed by the previously described colorimetric method (15) with a slight modification. In brief, the reaction mixture solution consisted of $0.1 \mathrm{ml}$ of prepared enzyme (final concentration, about $4 \mathrm{U} / \mathrm{ml}$ ), $0.1 \mathrm{ml}$ of HMGCoA (final concentration, $0.15 \mu \mathrm{mol} / \mathrm{l}), 0.1 \mathrm{ml}$ of the tested samples, $1.6 \mathrm{ml}$ of $0.1 \mathrm{~mol} / 1$ potassium phosphate buffer $(\mathrm{pH} 7.0)$ (containing $3.5 \mathrm{mmol} / 1$ EDTA, $10 \mathrm{mmol} / 1$ dithiothreitol, and $0.1 \mathrm{~g} / 1$ bovine serum albumin) and incubated at $37^{\circ} \mathrm{C}$ for $5 \mathrm{~min}$. Following that, $0.1 \mathrm{ml}$ of NADPH solution (final concentration, $0.30 \mu \mathrm{mol} / \mathrm{l}$ ) was added to the reaction solution. The solution was mixed immediately and assayed for changes of the optical density at $340 \mathrm{~nm}$ in $1-2 \mathrm{~min}$. HMGCoA reductase activity was expressed as $\mathrm{U} / \mathrm{mg}$ protein. The final concentrations of the tested samples incubated with the tested enzymes ranged from 0.01 to $100 \mu \mathrm{g} / \mathrm{ml}$. Simvastatin at the final of concentrations of 1,10 , and $100 \mu \mathrm{g} / \mathrm{ml}$ served as the positive control.

\section{Statistical analyses}

All values were expressed as the mean \pm S.D. Data were statistically analysed by ANOVA. The NewmanKeuls comparisons were used to determine the source of significant differences where appropriate. $P$ values less than 0.05 were considered statistically significant.

\section{Results}

Effect of $A C$ on serum triglyceride level in fructoseinduced hypertriglyceridemic mice

After acute administration of fructose, a significant increase in serum triglyceride level $(47 \%, P<0.05)$ was induced in fructose-induced control mice $(1.44 \pm 0.62$, $\mathrm{n}=10)$ compared with normal controls $(0.98 \pm 0.22$, $\mathrm{n}=10)$. However, AC $(0.40 \mathrm{~g} / \mathrm{kg})$ significantly prevented the increase $(0.86 \pm 0.27, \mathrm{n}=10)$ by $40 \%$ $(P<0.05)$ in the fructose-induced mice. Also, fenofibrate $(0.20 \mathrm{~g} / \mathrm{kg})$ significantly inhibited the increase $(0.64 \pm$ $0.15, \mathrm{n}=10)$ by $56 \%(P<0.01)$. 
Effect of $A C$ on hypercholesterolemia progression and regression in diabetic hypercholesterolemic mice

In the trial of hypercholesterolemic progression, untreated hypercholesterolemic mice exposed to highfat diets for 7 days progressively developed hypercholesterolemia compared with normal mice fed normal

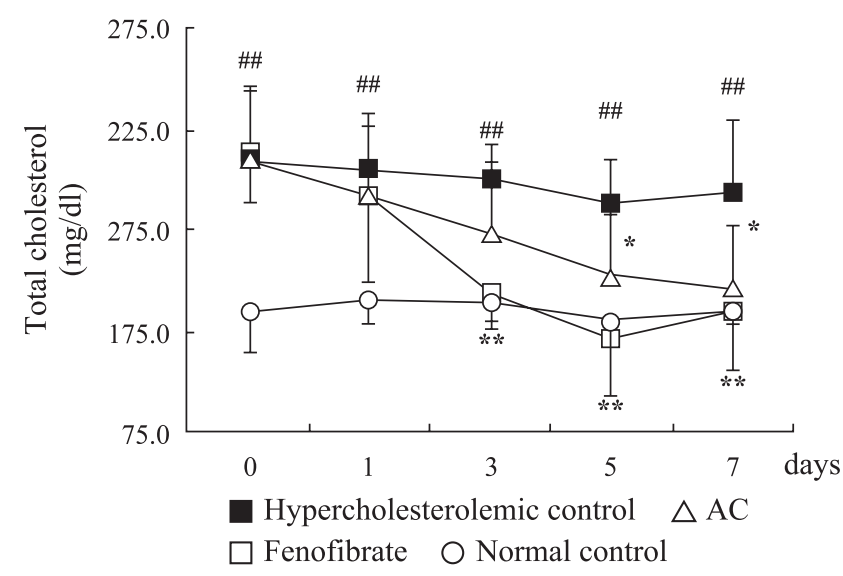

Fig. 2. Effect of the ethanolic extracts of Ananas comosus L. leaves (AC) on the regression of hypercholesterolemia in diabetic animals induced by alloxan and a high-fat diet at different days after subacute treatment. Data are each expressed as a mean \pm S.D., $\mathrm{n}=7$. ${ }^{\#} P<0.01$ : compared with the normal control group. ${ }^{*} P<0.05$, $* * P<0.01$ : compared with the hypercholesterolemic control group. Serum total cholesterol level remained at high levels in the untreated hypercholesterolemic mice even at the 7th day when high-fat diets that the mice had been fed were changed to normal chow but decreased to normal after 7 days of treatment of $\mathrm{AC}$ at a dose of $0.40 \mathrm{~g} / \mathrm{kg}$ and fenofibrate at a dose of $0.20 \mathrm{~g} / \mathrm{kg}$. diets (data were not shown). However, no significant inhibition activity in hypercholesterolemia progression was observed in hypercholesterolemic mice treated with AC $(0.40 \mathrm{~g} / \mathrm{kg})$ or fenofibrate $(0.20 \mathrm{~g} / \mathrm{kg})$ compared with untreated hypercholesterolemic controls. In the trial of hypercholesterolemic regression, serum total cholesterol in untreated hypercholesterolemic mice remained at a significantly high level $(180-220 \mathrm{mg} / \mathrm{dl})$ compared with normal controls even at the 7 th day when high-fat diets that the mice were fed had been changed to normal chow. However, significant hypocholesterolemic activity was observed in hypercholesterolemic mice after the treatment of $\mathrm{AC}$ $(0.40 \mathrm{~g} / \mathrm{kg})$ or fenofibrate $(0.20 \mathrm{~g} / \mathrm{kg})$ (Fig. 2). After 7 days of treatment, fasting serum total cholesterol level in AC or fenofibrate-treated groups almost reached a normal level $(120-140 \mathrm{mg} / \mathrm{dl})$.

\section{Effect of AC on acute hyperlipidemia in Triton WR-1339-} induced hyperlipidemic mice

At $24 \mathrm{~h}$ after the i.p. injection of Triton WR-1339, the treated mice showed a significant increase in serum triglyceride and total cholesterol compared with normal controls without the injection of Triton WR-1339 (Fig. 3). However, this increase was significantly attenuated by $\mathrm{AC}(0.40$ and $0.80 \mathrm{~g} / \mathrm{kg}$, respectively) and fenofibrate $(0.20 \mathrm{~g} / \mathrm{kg})$. At $48 \mathrm{~h}$, hypolipidemic effects were still seen in AC or fenofibrate-treated mice, although serum lipid levels were almost decreased to normal levels in all Triton WR-1339-treated mice.

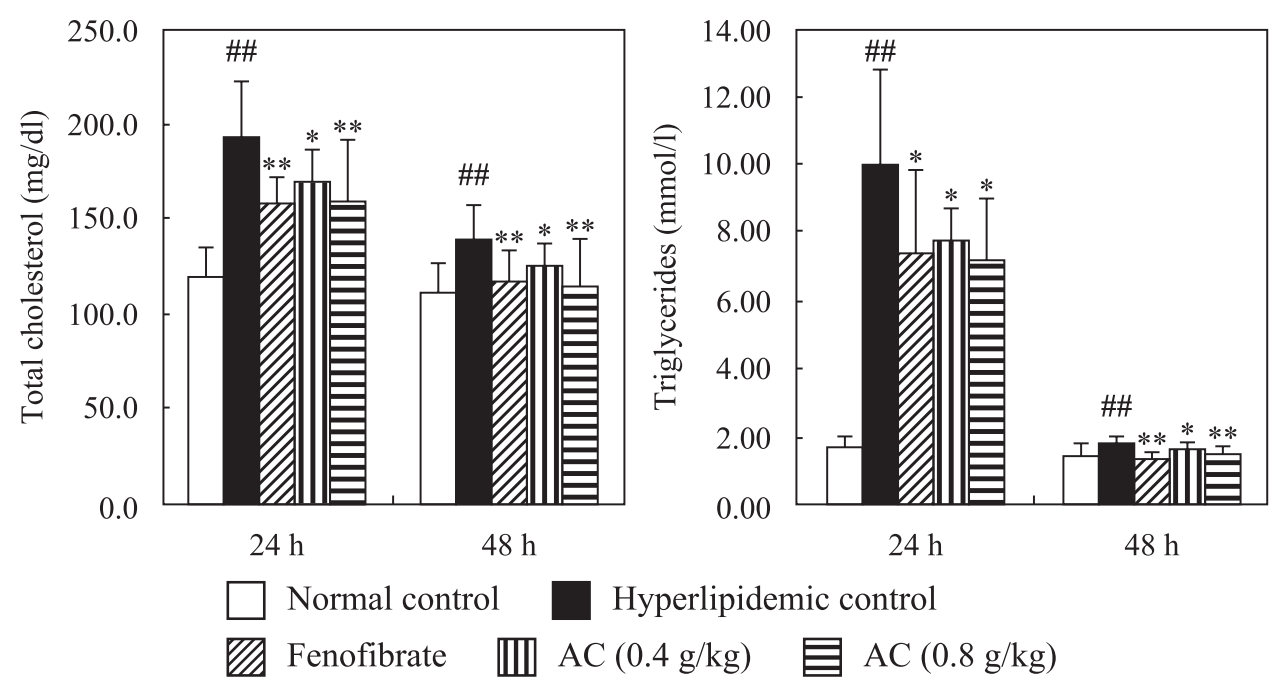

Fig. 3. Effect of the ethanolic extract of leaves of Ananas comosus L. (AC) on serum triglyceride and total cholesterol levels in Triton WR-1339-induced hyperlipidemic mice. Data are each expressed as a mean \pm S.D., $\mathrm{n}=10 .{ }^{\#} P<0.01$ : compared with the Triton WR-1339-untreated normal control group. ${ }^{*} P<0.05$, ${ }^{*} P<0.01$ : compared with Triton WR-1339-treated hyperlipidemic control group. Fenofibrate at a dose of $0.20 \mathrm{~g} / \mathrm{kg}$ and $\mathrm{AC}$ at doses of 0.40 and $0.80 \mathrm{~g} / \mathrm{kg}$ significantly inhibited the increase in serum total cholesterol and triglycerides in Triton WR-1339-treated hyperlipidemic mice at 24 and $48 \mathrm{~h}$. 
Effect of fenofibrate and AC on hepatomegly in normal mice

Fenofibrate caused a significant increase in liver /body weights $(\mathrm{g} / \mathrm{g})$ in mice $(0.0760 \pm 0.0110, P<0.01)$, but AC did not cause any change $(0.0403 \pm 0.0047)$ compared with those in untreated normal controls $(0.0402 \pm 0.0012)$ after two months of the administration.

Effect of AC on pancreatic lipase, LPL, and HMGCoA reductase activities in vitro

$\mathrm{AC}$ at the final concentrations of $0.01-1 \mu \mathrm{g} / \mathrm{ml}$ significantly inhibited the activity of pancreatic lipase in vitro. However, higher doses $(10-100 \mu \mathrm{g} / \mathrm{ml})$ had no significant effect (Fig. 4); this remains to be further investigated in future studies. Interestingly, $\mathrm{AC}$ at the final concentrations of $0.01-100 \mu \mathrm{g} / \mathrm{ml}$ significantly activated LPL activity by $200 \%-400 \%$ in vitro (Fig. 4 ). $\mathrm{AC}$ at the final concentrations of $0.01-100 \mu \mathrm{g} / \mathrm{ml}$ and simvastatin $(1-100 \mu \mathrm{g} / \mathrm{ml})$ significantly inhibited HMGCoA reductase activity by $20 \%-49 \%$ and $25 \%-$ $65 \%$ in vitro, respectively (Table 1 ).

\section{Discussion}

Plasma lipid levels are determined by exogenous lipid absorption and endogenous lipid synthesis and metabolism in body, which usually involves targets for lipidregulating drugs. Considering the complexity of both hypolipidemic mechanisms and components of the tested samples, mice may be more popular for investigation into mechanisms because they are easy to control
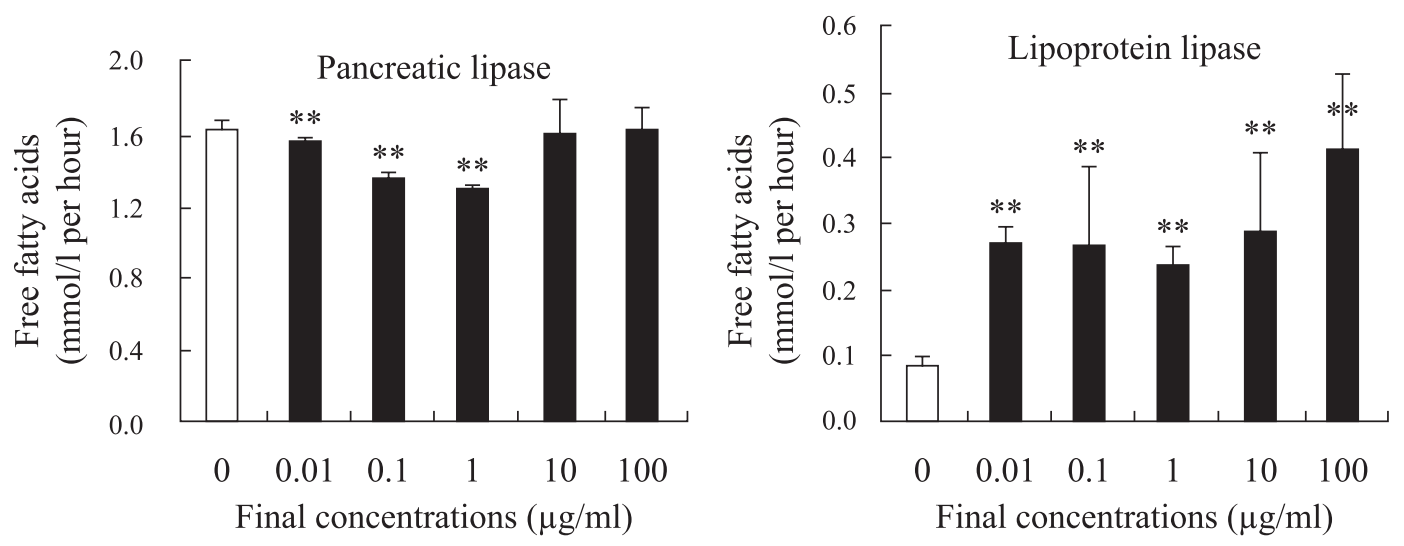

Control

$\mathrm{AC}$

Fig. 4. Effect of the ethanolic extracts of Ananas comosus L. leaves (AC) on both pancreatic and lipoprotein lipase in vitro at the final concentrations of $0.01-100 \mu \mathrm{g} / \mathrm{ml}$. Data are each expressed as a mean \pm S.D., $\mathrm{n}=6 .{ }^{* *} P<0.01 v s$ control. AC at low concentrations of $0.01-1 \mu \mathrm{g} / \mathrm{ml}$ significantly inhibited pancreatic lipase by $18 \%-22 \%$ but did not show any effect at highconcentrations of $10-100 \mu \mathrm{g} / \mathrm{ml}$ compared with the control. AC at concentrations of $0.01-100 \mu \mathrm{g} / \mathrm{ml}$ significantly activated lipoprotein lipase activity by $200 \%-400 \%$ compared with the control.

Table 1. Effect of the ethanolic extracts of Ananas comosus L. leaves (AC) on HMGCoA reductase activity in vitro

\begin{tabular}{lccc}
\hline Groups & $\begin{array}{c}\text { Final concentration } \\
(\mu \mathrm{g} / \mathrm{ml})\end{array}$ & $\begin{array}{c}\text { Enzyme activity } \\
(\mathrm{U} / \mathrm{mg})\end{array}$ & Inhibition percentage \\
\hline Control & & $3.76 \pm 0.11$ & \\
$\mathrm{AC}$ & 0.01 & $3.02 \pm 0.34^{* *}$ & 19.7 \\
& 0.1 & $2.63 \pm 0.12^{* *}$ & 30.1 \\
& 1 & $1.92 \pm 0.79^{* *}$ & 48.9 \\
& 10 & $2.00 \pm 0.32^{* *}$ & 46.8 \\
Simvastatin & 100 & $2.00 \pm 0.82^{* *}$ & 46.8 \\
& 1 & $2.78 \pm 0.22^{* *}$ & 25.9 \\
& 10 & $2.35 \pm 0.94^{* *}$ & 37.4 \\
& 100 & $1.33 \pm 0.30^{* *}$ & 64.5 \\
\hline
\end{tabular}

Mean \pm S.D., $\mathrm{n}=6 .{ }^{*} P<0.01$ vs control. 
and cost less than other animals such as rats or rabbits. It should be noted that a special mouse model involved in the specific processes involved in lipid metabolism may be helpful for elucidating hypolipidemic mechanisms of unknown components.

In the trial of hypercholesterolemia progression, cholesterol-enriched diets dominated the increase in serum total cholesterol. No significant effect was observed in AC- or fenofibrate-treated mice in the trial of hypercholesterolemia progression, which suggested that $\mathrm{AC}$ or fenofibrate did not effectively inhibit the absorption of intestinal dietary cholesterol. Fenofibrate that has a potent hypolipidemic effect did not effectively inhibit the increase in serum total cholesterol in the trial of hypercholesterolemia progression, which indirectly suggested that serum total cholesterol level might be determined by dietary cholesterol in this trial. In the trial of hypercholesterolemia regression, serum total cholesterol level was determined mainly by endogenous cholesterol metabolism when high-fat diets were replaced with normal chow. AC accelerated the fall in serum total cholesterol level, which suggested that AC inhibited the synthesis of endogenous cholesterol. Furthermore, in the in vitro trial, AC inhibited the activity of HMGCoA reductase. These results established the idea that the hypolipidemic effect of $\mathrm{AC}$ in vivo was correlated with inhibition of the activity of HMGCoA reductase, which might be associated with flavonoids enriched in AC since flavonoids could inhibit HMGCoA reductase activity (16). This trial suggested $\mathrm{AC}$ might share the same mechanism as statins.

$\mathrm{AC}$ attenuated the increase in serum triglyceride in the fructose-induced mice, indicating that AC played a role in inhibiting endogenous triglyceride synthesis (17). Triton WR-1339-treated mouse is a useful acute hyperlipidemic animal model (12) associated with inactive LPL. Triton WR-1339-induced hyperlipidemic mice treated with $\mathrm{AC}$ showed no increase in serum lipids at $24 \mathrm{~h}$, indicating that AC might activate LPL activity. Interestingly, AC activated plasma LPL activity in vitro at the appropriate ranges of dosage. LPL is a key enzyme related to plasma triglyceride metabolism. Furthermore, no activating effect was observed in intestinal pancreatic lipase exposed to $\mathrm{AC}$, which indicated that $\mathrm{AC}$ had specificity in activating lipase. In the following trial, we determined if this effect worked by the mechanism of PPAR $\alpha$ agonists.

When mice and rats are given $\operatorname{PPAR} \alpha$ agonists, fibrates, they exhibit peroxisome proliferation, hypertrophy, and hyperplasia (18). In the trial of hepatomegaly, fenofibrate can activate $\operatorname{PPAR} \alpha$ receptors, which results in hepatomegly in rodents after a long-term administration. We studied this special phenomenon to determine whether $\mathrm{AC}$ has a different mechanism from fenofibrate or not. AC caused no hepatomegaly in mice, different from fenofibrate, which suggested that $A C$ might have different action mechanism than fenofibrate. This simple and effective trial supplied significant scientific evidence and also could be a method to assess the effects of other PPAR $\alpha$ agonists. It might be particularly useful for those researchers or labs that are unable to conduct trials using the expensive techniques of molecular biology.

In conclusion, the hypolipidemic effect of AC may be related to inhibition of the activity of HMGCoA reductase and thereby selectively activate the activity of plasma LPL. AC may partly share an action mechanism with statins, but acts differently than fibrates. Therefore, AC may be able to serve as an adjuvant for fibrates that can be used in those patients who cannot tolerate the side-effect of fibrates. In addition, some simple animal model might be useful for determining the molecular action mechanisms of drugs even if no molecular biological methods are adopted.

\section{Acknowledgments}

The study was supported by National Natural Science Foundation of China (30572340), the Program of Science and Technology Research and Development of Tsinghua University (A2005568), and the Fund for Doctoral Station of the Ministry of Education, China (20060003072).

\section{References}

1 Frishman WH. Biologic markers as predictors of cardiovascular disease. Am J Med. 1998;104:18S-27S.

2 Stone NJ. Lipid management:current diet and drug treatment options. Am J Med. 1996;101:40S-49S.

3 Bhatnagar D. Lipid-lowering drugs in the management of hyperlipidemia. Pharmacol Therapeut. 1998;79:205-230.

4 Sripanidkulchai B, Na-nakorn S, Wongpanich V, Tanyakupta P. A behavioral investigation on utilization of medicinal plants for dysuria at Pon District, Khon Kaen. Khon Kaen University Research Journal. 2000;5:4-10.

5 Sripanidkulchai B, Wongpanich V, Laupattarakasem P, Suwansaksri J, Jirakulsomchok D. Diuretic effects of selected Thai indigenous medicinal plants in rats. J Ethnopharmacol. 2001;75:185-190.

6 Song LL. [Chinese herbs. chapter 8.] Shang Hai: Administrant Department of National Chinese Traditional Medicine; 1999. p. 296-297. (in Chinese)

7 Xie WD, Xing DM, Sun H, Wang W, Ding Y, Du LJ. The effects of Ananas comosus L. leaves on diabetic-dyslipidemic rats induced by alloxan and a high-fat/high-cholesterol diet. Am J Chin Med. 2005;33:95-105.

8 Xie WD, Wang W, Su H, Xing DM, Pan Y, Du LJ. Effect of ethanolic extracts of Ananas comosus L. Leaves on insulin 
sensitivity in rats and HepG2. Comp Biochm Phys C. 2006;143: 429-435.

9 Xie WD, Xing DM, Zhao YN, Su H, Meng Z, Chen YY, et al. A new tactic to treat postprandial hyperlipidemia in diabetic rats with gastroparesis by improving gastrointestinal transit. Eur $\mathbf{J}$ Pharmacol. 2006;510:113-120.

10 Xie WD, Du LJ. High-cholesterol diets impair short-term retention of memory in alloxan-induced diabetic mice, but not acquisition of memory in prediabetic mice. Life Sci. 2005; 77:481-495.

11 Cignarella A, Nastasi M, Cavalli E, Puglisi L. Novel lipidlowering properties of Vaccinium Myrtillus L. leaves, a traditional antidiabetic treatment, in several models of rat dyslipidaemia: a comparison with ciprofibrate. Thromb Res. 1996;84:311-322.

12 Silva RM, Santos FA, Maciel MA, Pinto AC, Rao VS. Effect of trans-dehydrocrotonin, a 19-nor-clerodane diterpene from Croton cajucara on experimental hypertriglyceridaemia and hypercholesterolaemia induced by Triton WR 1339 (tyloxapol) in mice. Planta Med. 2001;67:763-765.
13 Ninomiya K, Matsuda H, Shimoda H, Nishida N, Kasajima N, Yoshino T, et al. Carnosic acid, a new class of lipid absorption inhibitor from sage. Bioorg Med Chem Lett. 2004;14:19431946.

14 Zhang R, Liu Y, Liu BW. [Colorimetric assay method of plasma LPL and HL.] Journal of West China University of Medical Sciences. 1996;27:106. (in Chinese)

15 Zhang JT. [Modern experimental methods in pharmacology. 1st ed.] Beijing: United Publish house of Peking Medical University \& Peking Union Medical College; 1998. 1303-1304. (in Chinese)

16 Havsteen BH. The biochemistry and medical significance of the flavonoids. Pharmacol Ther. 2002;96:67-202.

17 Zavaroni I, Sander S, Scott S, Reaven GM. Effect of fructose feeding on insulin secretion and insulin action in the rat. Metabolism. 1980;10:970-973.

18 Cariello NF, Romach EH, Colton HM, Ni H, Yoon L, Falls JG, et al. Gene expression profiling of the PPAR-alpha agonist ciprofibrate in the cynomolgus monkey liver. Toxicol Sci. 2005;88:250-264. 